\title{
OPTIMASI SUHU DAN WAKTU MENGGUNAKAN RESPONSE SURFACE METHODOLOGY (RSM) PADA EKSTRAKSI OLEORESIN LIMBAH KULIT JERUK LEMON (Citrus limon (Linn.) Burm.F.) DENGAN BANTUAN GELOMBANG ULTRASONIK
}

Optimization of The Temperature and Time Using Response Surface Methodology (RSM) on Citrus Limon Peel (Citrus limon (Linn.) Burm.F.) Extraction with Ultrasonic Waves

\author{
I Gede Arie Mahendra Putra ${ }^{1}$, I Wayan Rai Widarta ${ }^{2}$, Putu Timur Ina ${ }^{2}$ \\ ${ }^{1}$ Mahasiswa Jurusan Imu dan Teknologi Pangan, Fakultas Teknologi Pertanian, Unud \\ ${ }^{2}$ Dosen Jurusan Imu dan Teknologi Pangan, Fakultas Teknologi Pertanian, Unud \\ PS Ilmu dan Teknologi Pangan, Fakultas Teknologi Pertanian, Universitas Udayana, \\ Kampus Bukit Jimbaran, Badung-Bali
}

\begin{abstract}
This study was aimed to determine the optimum temperature and extraction time of citrus lemon peel (Citrus limon (Linn.) Burm.F.) oleoresins by using Response Surface Methodology (RSM). The results showed that the optimum temperature and time of extraction with ultrasonic waves to produced oleoresins were $59,28^{\circ} \mathrm{C}$ and 72,57 minutes. The extraction process with optimum temperature and time produced citrus lemon peel oleoresin with yield and refractive index respectively 32,47\% and 1,4923. Meanwhile, the value of the density is equal to $1,3740 \mathrm{~g} / \mathrm{cm} 3$ and the chemical compound was identified by GC-MS instrument. The component that was found in the citrus lemon peel oleoresin were 1-propanone, 1,3,6 Octratriene, Propanoic Acid, 2Furancarboxaldehyde, 4-Vinyl-2-Methoxy-Phenol, 1-Pentene, Neryl Acetate, Geranic Acetate, $\alpha$-Bergamotene, Limonene, 2-Hexenal, 2-Bornanone, 2-Decyn-1-ol, Methyl Eugenol, Cis-P-Mentha-1(7),8-dien-2-ol, 1,4 Naphthalendione, Undecanal, Octadecanoic Acid, Pentadecanoic Acid, Decanoic Acid, 11-Octadecanoic Acid,GeranylButirate, Geranyl Propionate and 1,2-Benzenedicarboxylic Acid.
\end{abstract}

Keywords: citrus lemon peel, temperature, time, optimization, oleoresin.

\section{PENDAHULUAN}

Tanaman jeruk lemon merupakan salah satu komoditas hortikultura yang termasuk dalam familia rustaceae. Pembudidayaan buah jeruk lemon semakin meningkat seiring dengan perkembangan industri yang semakin pesat untuk memanfaatkan jeruk lemon sebagai salah satu bahan bakunya. Buah jeruk lemon banyak dimanfaatkan sebagai sari buah. Hal ini menyebabkan timbulnya suatu permasalahan baru yaitu limbah dari proses produksi sari buah jeruk lemon berupa kulit jeruk lemon.
Ewansiha et al. (2006) melaporkan bahwa kandungan fitokimia yang terdapat dalam ekstrak kulit jeruk lemon yaitu saponin, alkaloid, flavonoid, antrakuinon, minyak atsiri, resin, fenol, tanin, senyawa terpen, dan steroid, selain itu kulit jeruk lemon mengandung minyak atsiri yang bersumber dari kantong minyak yang berbentuk oval dengan diameter yang bervariasi dari $0,4-0,6 \mathrm{~mm}$. Menurut Frenkel dan Dudai (2016) flavor lemon tergantung dari kandungan citral. Selain itu, flavor pada lemon juga disebabkan karena lemon mengandung limonen, neral, geranial, neryl acetate, geranyl acetate, linalool, dan

\footnotetext{
*Korespondensi Penulis:

E-mail: arimahendra96@gmail.com ${ }^{1}$
} 
terpineol.Benvenuti et al. (2001) melaporkan bahwa kulit jeruk lemon mengandung dlimonen dari kelenjar limonoid sebesar 45\%$75 \%$.Ekstraksi kulit jeruk lemon belum banyak dilakukan, namun dengan berkembangnya berbagai industri, oleoresin merupakan salah satu alternatif yang potensial. Potensi produksi oleoresin adalah dapat dijadikan sebagai bahan flavor pada produk pangan. Produksi oleoresin juga dapat mengatasi kelemahan dari bahan segarnya. Kelebihan produksi oleoresin dibandingkan bahan segarnya adalah lebih higienis, memiliki keseragaman mutu, aroma yang dimiliki lebih tajam dan memiliki daya simpan yang lama. Oleoresin adalah gabungan dari resin dan minyak atsiri yang dapat diperoleh dari ekstraksi bagian tanaman tertentu dengan menggunakan pelarut organik. Oleoresin berbentuk padat atau semi padat dan biasanya konsistensinya kental (Whitteley et al., 1952 dalam Desmawarni, 2007).

Pengambilan oleoresin dari suatu tanaman dapat dilakukan dengan ekstraksi. Ekstraksi dapat dilakukan dengan beberapa metode, salah satunya yaitu ekstraksi dengan bantuan gelombang ultrasonik. Balachandran et al. (2006), melaporkan bahwa penggunaan ultrasonik akan menaikkan difusifitas dan proses perpindahan massa mencapai maksimum pada waktu yang singkat, sehingga proses ekstraksi dapat berlangsung lebih cepat.Faktor-faktor yang mempengaruhi proses ekstraksi oleoresin diantaranya adalah waktu dan suhu ekstraksi.Yuliantari et al. (2017) melaporkan bahwa interaksi antara suhu dan waktu proses ekstraksi menggunakan ultrasonik berpengaruh sangat nyata terhadap rendemen ekstrak yang dihasilkan.

Penelitian terkait optimasi proses ekstraksi kulit jeruk lemon menggunakan metode ultrasonik belum banyak dilaporkan, Proses ekstraksi pada bahan yang berbeda akan menghasilkan suhu dan waktu optimum yang berbeda, seperti proses optimasi ekstraksi oleoresin dengan menggunakan metode ultrasonik yang telah diaplikasikan pada kulit kayu manis seperti yang dilaporkan oleh Rupini et al. (2017) bahwa suhu optimum ekstraksi oleoresin kulit kayu manis menggunakan metode ultrasonik yaitu pada suhu $58,3^{\circ} \mathrm{C}$ selama 77 menit, menghasilkan rendemen sebesar 26,577\%. Selain itu, Arpi et al. (2013) melakukan penelitian serupa tentang ekstraksi oleoresin limbah penyulingan pala menggunakan ultrasonik melaporkan bahwa suhu ekstraksi $60^{\circ} \mathrm{C}$ memberikan hasil rendemen tertinggi dan indeks bias oleoresin yang sesuai dengan ketetapan EOA (Essential Oil Association of the USA. Untuk itu maka dilakukan penelitian terhadap waktu dan suhu ekstraksi oleoresin pada kulit buah jeruk lemon. Response Surface Methodology (RSM) digunakan agar penelitian yang dilaksanakan lebih hemat dan efisien. Oleh karena itu, dilakukan optimasi suhu dan waktu menggunakan Respon Surface Methodology (RSM) pada ekstraksi oleoresin limbah kulit jeruk lemon dengan bantuan gelombang ultrasonik.

\section{METODE PENELITIAN}

\section{Tempat dan waktu penelitian}

Penelitian ini dilaksanakan di Laboratorium Pengolahan Pangan, Laboratorium Analisis Pangan, Laboratorium Mikrobiologi Pangan dan Laboratorium Biokimia dan Nutrisi, Program Studi Ilmu dan Teknologi Pangan, Fakultas Teknologi Pertanian, Universitas Udayana, Laboratorium PT. Bali Extract Utama dan Laboratorium Kimia Organik Fakultas Matematika dan Ilmu Pengetahuan Alam, Universitas Gadjah Mada Yogyakarta.

\section{Bahan dan alat}

Bahan yang digunakan dalam penelitian ini adalah bagian kuning kulit jeruk lemon segar yang didapatkan di UD Feny Denpasar, aquades, dan pelarut etanol.

Alat-alat yang digunakan pada penelitian ini yaitu ayakan 60 mesh, Sonikator (Elmasonic S450/(H)),rotary vakum 
evaporator (Ika Labortechnik), timbangan analitik (shimadzu), timbangan (Fuji), spatula, gelas ukur (Pyrex), erlenmeyer (Pyrex), refraktometer (ATAGO NAR-1T Liquid), piknometer (Pyrex), kertas whatman no.1, blender (Phillips), penyaringan vakum, aluminium foil, tisu dan Instrumen Gas Chromathography-Mass

Spechtrometry

(GCMS- QP2010S SHIMADZU).

\section{Pelaksanaan penelitian \\ Persiapan sampel}

Persiapan sampel meliputi persiapan bahan, pengeringan, pembuatan bubuk kulit jeruk lemon dan persiapan proses ekstraksi. Kulit jeruk lemon dibersihkan dan dipotong dengan ukuran $\pm 1 \mathrm{~cm}$. Potongan kulit jeruk lemon dioven pada suhu $55^{\circ} \mathrm{C}$ selama 15 jam. Kulit jeruk lemon dihancurkan dengan blender sampai halus, kemudian diayak menggunakan ayakan 60 mesh hingga didapat bubuk kulit jeruk lemon (Rafsanjani dan Putri, 2015), yang telah dimodifikasi).

\section{Proses ekstraksi oleoresin kulit jeruk lemon}

Bubuk kulit jeruk lemon ditimbang sebanyak 15 gram dan ditambahkan pelarut etanol 96\% sebanyak $150 \mathrm{ml}$ (rasio bahan dengan pelarut adalah 1:10 (b/v)). Proses ekstraksi dilakukan menggunakan bantuan gelombang ultrasonik. Suhu dan waktu ekstraksi disesuaikan dengan perlakuan pada Tabel 2.Bahan yang telah melalui proses ekstraksi kemudian disaring menggunakan kertas whatman No.1 dengan bantuan alat penyaringan vakum. Filtrat yang diperoleh kemudian diuapkan pelarutnya menggunakan alat rotary vacuum evaporator. Evaporasi dilakukan dengan tekanan 80 mbar, temperatur $40^{\circ} \mathrm{C}$ dan putaran $100 \mathrm{rpm}$ (Silfia, 2013 yang telah dimodifikasi).

\section{Analisis data}

Penelitian ini menggunakan central composite design (CCD) dua faktor. Penentuan titik pusat dilakukan sebelum dioptimasi menggunakan metode permukaan respon, suhu pengamatan dilakukan pada suhu $50^{\circ} \mathrm{C}, 60^{\circ} \mathrm{C}$ dan $70^{\circ} \mathrm{C}$. Waktu pengamatan dilakukan pada waktu 46, 66, dan 86 menit. Analisis data dalam penelitian ini menggunakan bantuan software MINITAB17. Variabel bebas, kode dan nilai yang dioptimasi serta kombinasi perlakuan optimasi ekstraksi oleoresin kulit jeruk lemon dapat dilihat pada Tabel 1 dan 2.

Tabel 1. Level variabel bebas, kode dan nilai yang dioptimasi

\begin{tabular}{|c|c|c|c|c|c|}
\hline \multirow{2}{*}{ Variabel } & \multicolumn{5}{|c|}{ Kode dan Nilai } \\
\hline & $-1,414$ & -1 & 0 & +1 & $+1,414$ \\
\hline Suhu & & & & & \\
\hline $\begin{array}{l}\text { Ekstraksi, A } \\
\left({ }^{\circ} \mathrm{C}\right)\end{array}$ & 45,86 & 50 & 60 & 70 & 74,14 \\
\hline $\begin{array}{l}\text { Waktu } \\
\text { Ekstraksi, B } \\
\text { (Menit) }\end{array}$ & 37,72 & 46 & 66 & 86 & 94,28 \\
\hline
\end{tabular}

Tabel 2. Kombinasi perlakuan optimasi ekstraksi oleoresin kulit jeruk lemon

\begin{tabular}{lcccc}
\hline \multirow{2}{*}{ No } & \multicolumn{3}{c}{ Kode } & \multicolumn{2}{c}{ Perlakuan } \\
\cline { 2 - 5 } & A & B & Suhu & Waktu \\
\hline 1 & -1 & -1 & 50 & 46 \\
2 & +1 & -1 & 70 & 46 \\
3 & -1 & +1 & 50 & 86 \\
4 & +1 & +1 & 70 & 86 \\
5 & $-1,414$ & 0 & 45,86 & 66 \\
6 & $+1,414$ & 0 & 74,14 & 66 \\
7 & 0 & $-1,414$ & 60 & 37,72 \\
8 & 0 & $+1,414$ & 60 & 94,28 \\
9 & 0 & 0 & 60 & 66 \\
10 & 0 & 0 & 60 & 66 \\
11 & 0 & 0 & 60 & 66 \\
12 & 0 & 0 & 60 & 66 \\
13 & 0 & 0 & 60 & 66 \\
\hline
\end{tabular}

\section{Parameter yang diamati}

Parameter yang diamati pada penelitian ini meliputi rendemen (AOAC, 1990), indeks bias menggunakan refraktometer (AOAC, 1990), berat jenis menggunakan piknometer (AOAC, 1990), uji warna menggunakan colorimeter dan uji identifikasi komponen oleoresin menggunakan bantuan instrumen GC-MS. 


\section{HASIL DAN PEMBAHASAN}

Hasil analisis rendemen dan indeks bias oleoresin kulit jeruk lemon dilihat pada Tabel 3.

Tabel 3. Hasil analisis rendemen dan indeks bias oleoresin kulit jeruk lemon

\begin{tabular}{ccccc}
\hline No & Suhu & Waktu & Rendemen(\%) & $\begin{array}{c}\text { Indeks } \\
\text { Bias }\end{array}$ \\
\hline 1 & 50 & 46 & $27,62 \%$ & 1,4920 \\
2 & 70 & 46 & $28,91 \%$ & 1,4940 \\
3 & 50 & 86 & $29,63 \%$ & 1,4900 \\
4 & 70 & 86 & $30,48 \%$ & 1,4960 \\
5 & 45,85 & 66 & $29,44 \%$ & 1,4970 \\
6 & 74,14 & 66 & $26,54 \%$ & 1,4910 \\
7 & 60 & 37,71 & $29,66 \%$ & 1,4920 \\
8 & 60 & 94,28 & $30,53 \%$ & 1,4870 \\
9 & 60 & 66 & $30,78 \%$ & 1,4850 \\
10 & 60 & 66 & $30,85 \%$ & 1,4830 \\
11 & 60 & 66 & $31,22 \%$ & 1,4850 \\
12 & 60 & 66 & $31,08 \%$ & 1,4860 \\
13 & 60 & 66 & $31,13 \%$ & 1,4850 \\
\hline
\end{tabular}

\section{Rendemen}

Analisis rendemen oleoresin kulit jeruk lemon mendapatkan hasil regresi dengan model persamaan regresi yaitu $\mathrm{Y}=-29,7$ $+1,790 \mathrm{X}_{1}+0,205 \mathrm{X}_{2}-0,01482 \mathrm{X}_{1}^{2} \quad$ $0,001073 \mathrm{X}_{2}^{2}-0,00055 \mathrm{X}_{1} \mathrm{X}_{2}$. Notasi $\mathrm{Y}$ pada model persamaan regresi menunjukkan rendemen oleoresin kulit jeruk lemon, $\mathrm{X}_{1}$ merupakan suhu proses ekstraksi dan $\mathrm{X}_{2}$ merupakan waktu proses ekstraksi dengan koefisien determinasi $\left(\mathrm{R}^{2}\right)=0,7686$. Nilai koefisien determinasi memberikan pengertian bahwa pengaruh suhu dan waktu terhadap rendemen oleoresin kulit jeruk lemon sebesar $76,86 \%$, sedangkan sisanya sebesar $23,14 \%$ dipengaruhi oleh faktor-faktor lainnya yang tidak dapat dijelaskan oleh respon. Korelasi suhu dan waktu terhadap rendemen oleoresin kulit jeruk lemon ditentukan oleh koefisien korelasi (r). Nilai koefisien korelasi yang didapat yaitu sebesar 0,8767 yang berarti korelasi antara suhu dan waktu memiliki korelasi yang sangat kuat. Hal ini dilaporkan oleh Sarwono (2006) yaitu nilai koefisien korelasi $>0,75-0,99$ dapat diartikan bahwa korelasi antara dua variabel memiliki korelasi yang sangat kuat.

Kondisi optimum respon yang didapatkan berdasarkan nilai optimasi terhadap rendemen oleoresin kulit jeruk lemon diketahui bahwa nilai optimum suhu yaitu $59,00^{\circ} \mathrm{C}$ dengan waktu proses ekstraksi selama 79,99 menit. Rendemen oleoresin kulit jeruk lemon yang diprediksi pada titik tersebut yaitu sebesar $31,24 \%$

Grafik surface plot dan contour plot dari rendemen oleoresin kulit jeruk lemon dapat dilihat pada Gambar 1 dan 2. Perubahan warna pada grafik contour plot menunjukkan terdapat perbedaan rendemen dengan kombinasi suhu dan waktu yang berbeda.

Gambar 1 menunjukkan bahwa rendemen oleoresin kulit jeruk lemon dipengaruhi oleh suhu dan waktu ekstraksi. Peningkatan nilai rendemen oleoresin berbanding lurus dengan meningkatnya suhu dan waktu proses ekstraksi hingga mencapai titik optimum. Hal serupa dilaporkan oleh Fuadi (2012) bahwa rendemen oleoresin yang diperoleh dipengaruhi oleh suhu dan waktu ekstraksi. Semakin lama waktu ekstraksi maka rendemen oleoresin yang diperoleh akan semakin tinggi, namun ketika waktu yang optimal telah tercapai, maka nilai rendemen tidak berbeda secara signifikan. Selain itu, Solehudin (2001) melaporkan bahwa pemanasan dengan suhu tinggi dapat menyebabkan komponen minyak atsiri menguap sehingga jumlahnya dapat berkurang, namun proses ekstraksi yang dilakukan pada suhu rendah dan waktu yang singkat akan menyebabkan komponen tidak terekstrak dengan maksimal karena proses difusi tidak berlangsung secara optimal sehingga oleoresin masih banyak yang tertinggal di dalam jaringan bahan.

Hal serupa telah dibuktikan oleh penelitian Ramadhan dan Haries (2010) yang melaporkan bahwa rendemen oleoresin akan meningkat diikuti dengan interaksi bahan dengan pelarut didalam proses ekstraksi pada suhu dan waktu yang meningkat hingga 
mencapai titik optimal. Kenaikan suhu pada proses ekstraksi akan menyebabkan molekul perlarut bergerak semakin cepat dan acak, peningkatan waktu pada proses ekstraksi dapat menyebabkan kontak antara pelarut dan bahan semakin lama sehingga bahan dapat terekstrak secara maksimal, selain itu kenaikan suhu juga dapat memudahkan pelarut berdifusi dan masuk ke dalam pori-pori bahan dan dapat melarutkan bahan dengan sempurna (Assagaf et al.,2012)

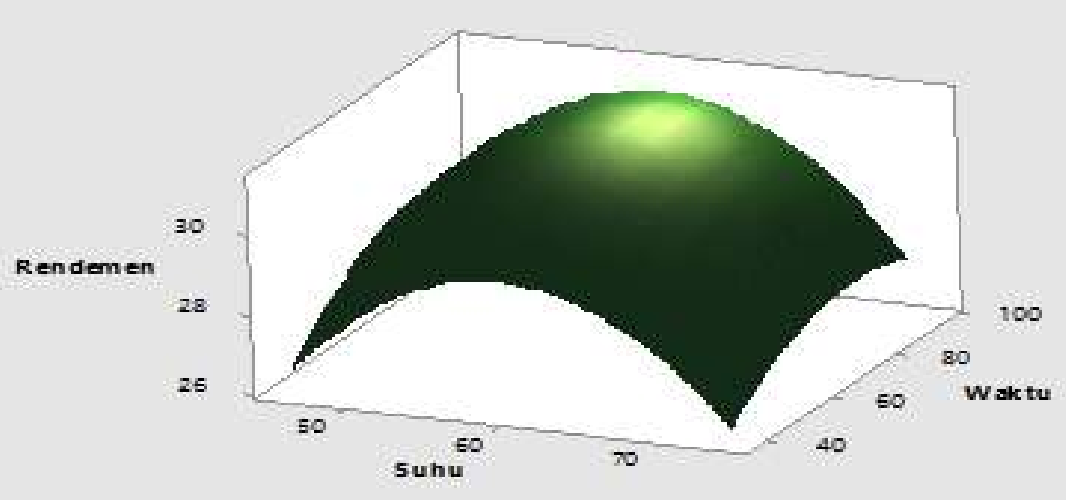

Gambar 1. Grafik surface plot rendemen oleoresin kulit jeruk lemon terhadap suhu dan waktu
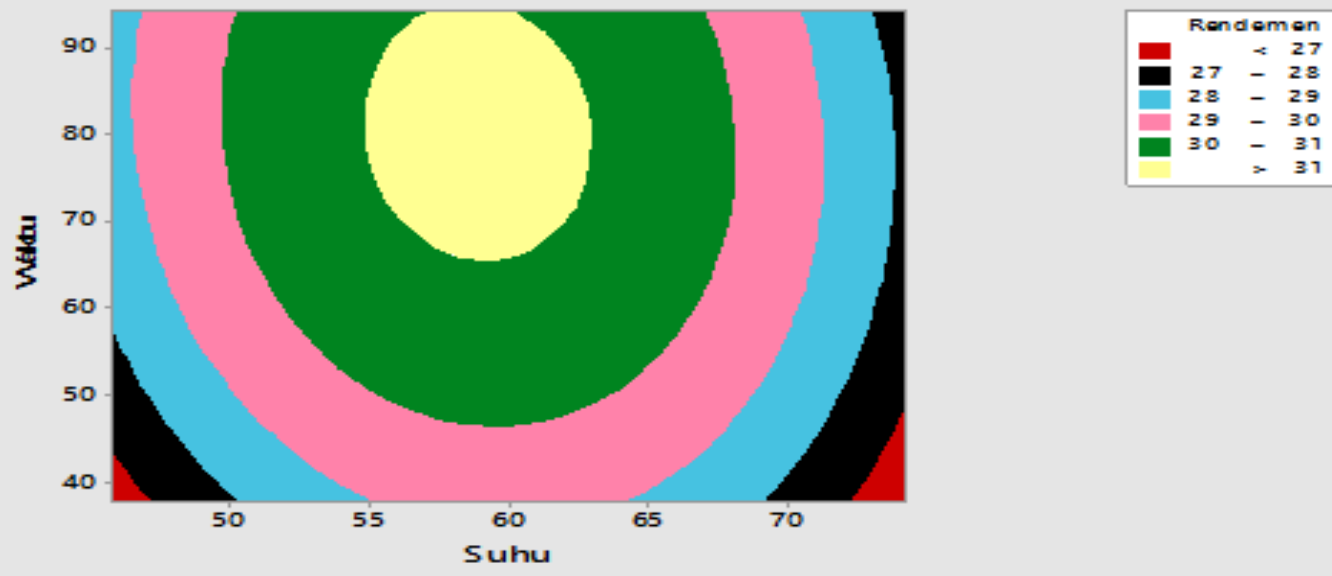

Gambar 2. Contour plot rendemen oleoresin kulit jeruk lemon terhadap suhu dan waktu

Gambar 2 menunjukkan bahwa rendemen oleoresin kulit jeruk lemon dipengaruhi oleh suhu dan waktu ekstraksi. Peningkatan nilai rendemen oleoresinberbanding lurus dengan meningkatnya suhu dan waktu proses ekstraksi hingga mencapai titik optimum. Hal serupa dilaporkan oleh Fuadi (2012) bahwa rendemen oleoresin yang diperoleh dipengaruhi oleh suhu dan waktu ekstraksi. Semakin lama waktu ekstraksi maka rendemen oleoresin yang diperoleh akan semakin tinggi, namun ketika waktu yang optimal telah tercapai, maka nilai rendemen tidak berbeda secara signifikan.Selain itu, Solehudin (2001) melaporkan bahwa pemanasan dengan suhu tinggidapat menyebabkan komponen minyak atsiri menguap sehingga jumlahnya dapat berkurang, namun proses ekstraksi yang dilakukan pada suhu rendah dan waktu yang singkat akan menyebabkan komponen tidak terekstrak dengan maksimal karena proses difusi tidak berlangsung secara optimal 
sehingga oleoresin masih banyak yang tertinggal di dalam jaringan bahan.

Hal serupa telah dibuktikan oleh penelitian Ramadhan dan Haries (2010) yang melaporkan bahwa rendemen oleoresin akan meningkat diikuti dengan interaksi bahan dengan pelarut didalam proses ekstraksi pada suhu dan waktu yang meningkat hingga mencapai titik optimal. Kenaikan suhu pada proses ekstraksi akan menyebabkan molekul perlarut bergerak semakin cepat dan acak, peningkatan waktu pada proses ekstraksi dapat menyebabkan kontak antara pelarut dan bahan semakin lama sehingga bahan dapat terekstrak secara maksimal, selain itu kenaikan suhu juga dapat memudahkan pelarut berdifusi dan masuk ke dalam pori-pori bahan dan dapat melarutkan bahan dengan sempurna (Assagaf et al., 2012).

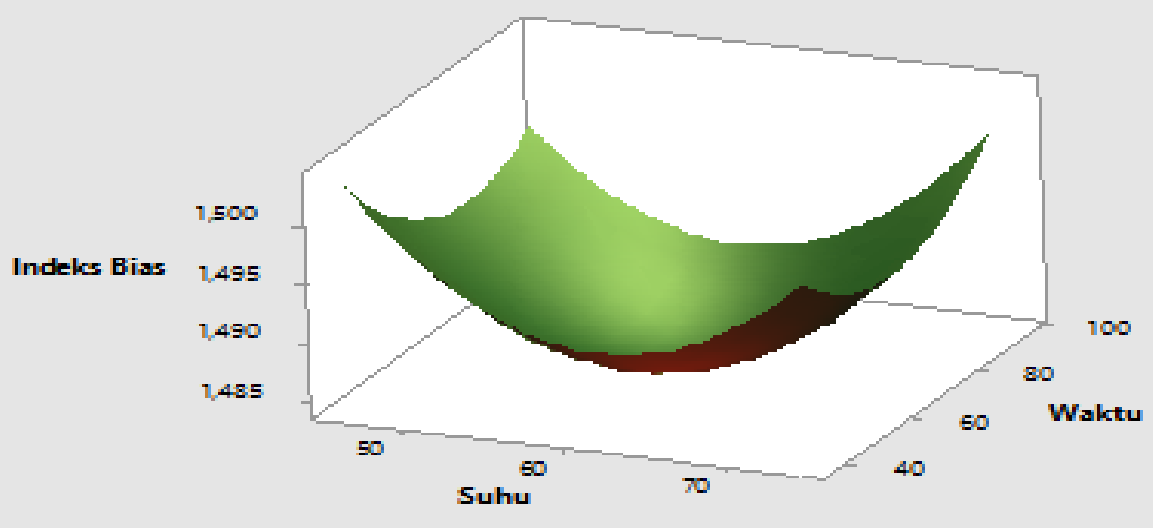

Gambar 3. Grafik surface plot indeks bias oleoresin kulit jeruk lemon terhadap suhu dan waktu
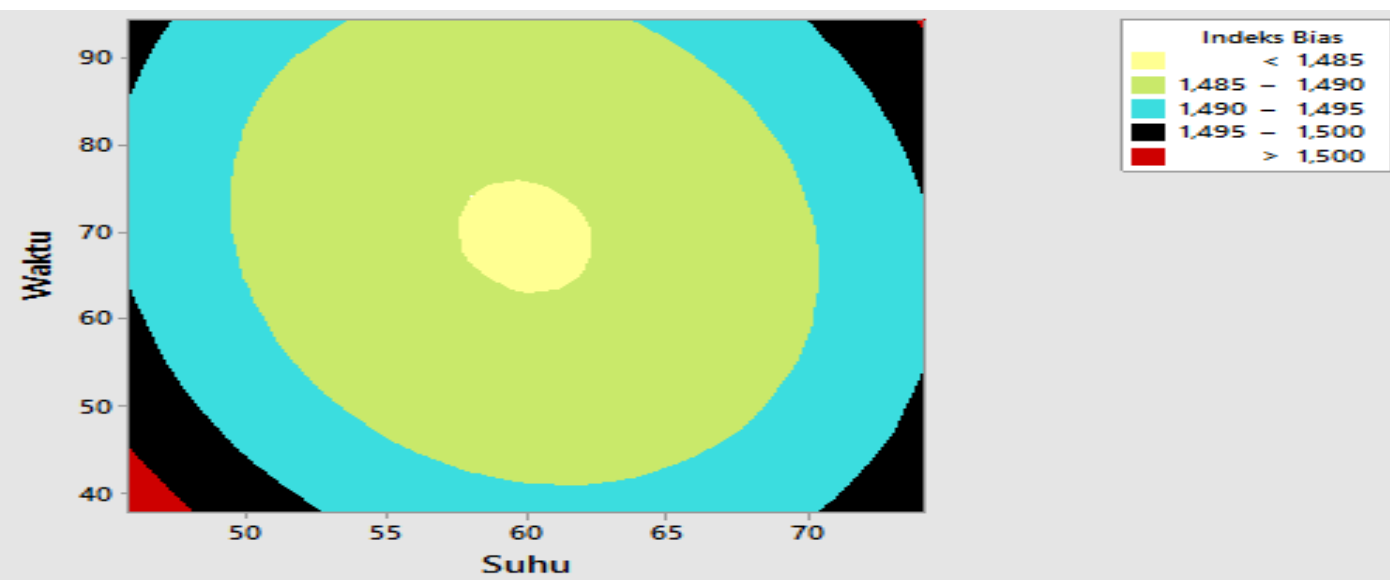

Gambar 4. Grafik contour plot indeks bias oleoresin kulit jeruk lemon terhadap suhu dan waktu

\section{Indeks bias}

Hasil yang diperoleh pada pengujian indeks bias oleoresin kulit jeruk lemon berkisar antara 1,4830-1,4970. Model persamaan regresi optimasi suhu dan waktu ekstraksi oleoresin kulit jeruk lemon yang didapatkan terhadap nilai indeks bias oleoresin adalah $\mathrm{Y}=1,7137$ -
$0,00623 \mathrm{X}_{1}-0,001223 \mathrm{X}_{2}+0,000049 \mathrm{X}_{1}^{2}+$ $0,000007 \mathrm{X}_{2}^{2}+0,000005 \mathrm{X}_{1} \mathrm{X}_{2}$. Notasi $\mathrm{Y}$ merupakan indeks bias oleoresin kulit jeruk lemon. $\mathrm{X}_{1}$ merupakan suhu proses ekstraksi dan $\mathrm{X}_{2}$ merupakan waktu proses ekstraksi. Koefisien determinasi $\left(\mathrm{R}^{2}\right)$ yang diperoleh yaitu 0,8114 yang berarti bahwa suhu dan 
waktu memiliki pengaruh sebesar $81,14 \%$ terhadap indeks bias oleoresin, sedangkan sisanya sebesar $18,86 \%$ dipengaruhi oleh faktor-faktor lainnya yang tidak dapat dijelaskan oleh respon. Korelasi suhu dan waktu terhadap indeks bias oleoresin kulit jeruk lemon ditentukan oleh koefisien korelasi (r). Nilai koefisien korelasi yang didapat yaitu sebesar 0,9008 yang berarti korelasi antara suhu dan waktu memiliki korelasi yang sangat kuat. Hal ini dilaporkan oleh Sarwono (2006) yaitu nilai koefisien korelasi $>0,75-0,99$ dapat diartikan bahwa korelasi antara dua variabel memiliki korelasi yang sangat kuat.

Hasil grafik surface plot dan contour plot dari analisis indeks bias oleoresin masingmasing dapat dilihat pada Gambar 3 dan 4 . Perbedaan warna pada surface plot dan contour plot menunjukkan adanya perbedaan hasil analisis indeks bias oleoresin dengan kombinasi suhu dan waktu yang berbeda.
Grafik surface plot menunjukkan bahwa indeks bias oleoresin kulit jeruk lemon dipengaruhi oleh suhu dan waktu ekstraksi. Suhu dan waktu ekstraksi tertentu akan menyebabkan indeks bias oleoresin menurun hingga titik optimalnya, namun setelah titik optimalnya terlewati nilai indeks bias akan meningkat kembali. Berdasarkan analisis optimasi yang diperoleh dari respon, titik optimum nilai indeks bias oleoresin kulit jeruk lemon yaitu pada suhu $59,85^{\circ} \mathrm{C}$ dengan waktu proses ekstraksi selama 69,14 menit. Titik-titik tersebut diprediksi akan menghasilkan nilai indeks bias sebesar 1,4847.

Hartuti dan Supardan(2013) melaporkan bahwa peningkatan suhu dan waktu ekstraksi yang digunakan akan menurunkan nilai indeks bias oleoresin yang dihasilkan. Namun pada temperatur ekstraksi lebih besar dari titik optimum, nilai indeks bias yang dihasilkan akan meningkat kembali.

Tabel 4. Perbandingan hasil validasi secara nyata dengan model respon optimasi

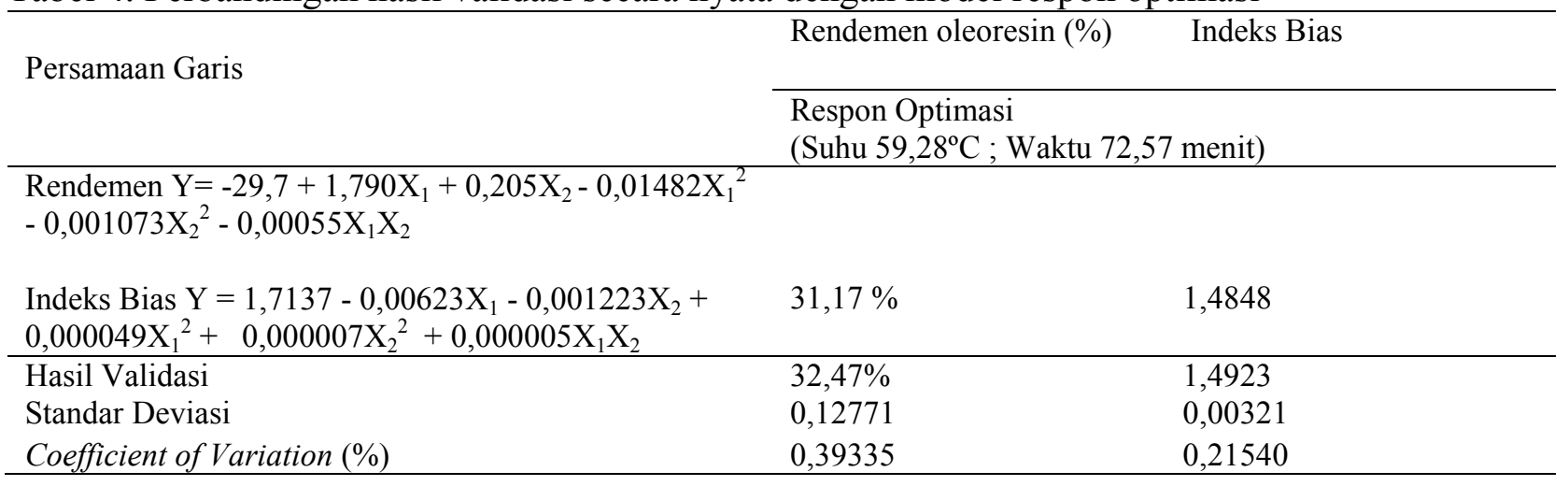

\section{Validasi kondisi optimum}

Validasi kondisi optimum merupakan proses untuk membuktikan bahwa suatu respon atau model dapat memberikan hasil yang sesuai. Kondisi optimum untuk suhu dan waktu proses ekstraksi oleoresin kulit jeruk lemon yaitu pada suhu $59,28^{\circ} \mathrm{C}$ dan waktu 72,57 menit dengan nilai D (Desirability) sebesar 0,9290. Perbandingan hasil validasi dengan model respon optimasi terhadap variabel dapat dilihat Tabel 4.

Hasil validasi respon optimasi proses ekstraksi oleoresin kulit jeruk lemon pada kondisi optimum dilakukan pada suhu $59,28^{\circ} \mathrm{C}$ dan waktu 72,57 menit. Rendemen dan indeks bias oleoresin kulit jeruk lemon yang didapatkan pada proses validasi kondisi optimum sebesar $32,47 \%$ dan 1,4923. Standar deviasi yang diperoleh untuk rendemen dan indeks bias oleoresin kulit jeruk lemon hasil validasi kondisi optimum yaitu 0,12771 dan 0,00321 dengan coefficient of variation yakni 0,39335 dan 0,21540 . 
Karakteristik dan komponen oleoresin kulit jeruk lemon yang dihasilkan pada suhu dan jeruk lemon pada kondisi optimum

Karakteristik dan komponen oleoresin kulit waktu optimum yaitu dapat dilihat pada Tabel 5 dan 6.

Tabel 5. Karakteristik oleoresin kulit jeruk lemon

\begin{tabular}{lll}
\hline No & Karakteristik & Hasil \\
\hline 1 & Rendemen & $32,44 \% \pm 0,127$ \\
2 & Indeks Bias & $1,4923 \pm 0,003$ \\
3 & Berat Jenis & $1,3740 \pm 0,001 \mathrm{~g} / \mathrm{cm}^{3}$ \\
4 & Aroma & Khas Lemon \\
5 & Warna & Kuning $\left(\mathrm{L}=54,3 ; \mathrm{a}^{*}=-6,5 ; \mathrm{b}^{*}=57,6\right)$ \\
6 & Bentuk & Cairan Kental \\
\hline
\end{tabular}

Tabel 6. Hasil identifikasi komponen oleoresin kulit jeruk lemon menggunakan GC-MS

\begin{tabular}{|c|c|c|c|}
\hline Peak & Retention Time (RT) & $\%$ Area & Nama Komponen \\
\hline 1 & 12,317 & 0,17 & 1-Propanone \\
\hline 2 & 14,101 & 1,30 & 1,3,6 Octatriene \\
\hline 3 & 17,012 & 0,96 & 3-Cyclohexene-1-Acetaldehyde \\
\hline 4 & 18,650 & 0,87 & Propanoic Acid \\
\hline 5 & 19,312 & 43,24 & 2-Furancarboxaldehyde \\
\hline 6 & 20,136 & 6,64 & 4-Vinyl-2-Methoxy-Phenol \\
\hline 7 & 20,450 & 0,40 & 1-Pentene \\
\hline 8 & 21,392 & 1,07 & Neryl Acetate \\
\hline 9 & 21,533 & 0,48 & Geranic Acid \\
\hline 10 & 21,917 & 0,33 & Geranyl Acetate \\
\hline 11 & 23,491 & 0,59 & $\alpha$-Bergamotene \\
\hline 12 & 25,432 & 1,85 & Limonene \\
\hline 13 & 26,407 & 1,31 & 2-Hexenal \\
\hline 14 & 27,583 & 0,48 & 2-Bornanone \\
\hline 15 & 27,938 & 0,82 & 2-Decyn-1-ol \\
\hline 16 & 29,080 & 11,64 & Methyl Eugenol \\
\hline 17 & 29,261 & 0,62 & Limonene \\
\hline 18 & 29,400 & 0,28 & Cis-P-Mentha-1(7),8-dien-2-ol \\
\hline 19 & 31,592 & 0,59 & 1,4 Naphthalendione \\
\hline 20 & 32,678 & 0,44 & Undecanal \\
\hline 21 & 34,987 & 0,44 & Octadecanoic Acid \\
\hline 22 & 36,150 & 7,58 & Pentadecanoic Acid \\
\hline 23 & 36,400 & 0,57 & Decanoic Acid \\
\hline 24 & 38,537 & 0,52 & 11-Octadecanoic Acid \\
\hline 25 & 38,984 & 0,72 & Pentadecanoic Acid \\
\hline 26 & 39,417 & 0,30 & Geranyl Butirate \\
\hline 27 & 39,714 & 8,36 & 10-Undecanal \\
\hline 28 & 40,195 & 5,24 & Octadecanoic Acid \\
\hline 29 & 43,038 & 0,51 & Neryl Acetate \\
\hline 30 & 46,455 & 0,78 & 1,2-Benzenedicarboxylic Acid \\
\hline 31 & 49,485 & 0,38 & Geranyl Propionate \\
\hline 32 & 52,121 & 0,48 & Neryl Acetate \\
\hline
\end{tabular}




\section{KESIMPULAN DAN SARAN}

\section{Kesimpulan}

Berdasarkan hasil penelitian ini dapat disimpulkan bahwa suhu dan waktu optimum pada proses ekstraksi menggunakan bantuan gelombang ultrasonik untuk menghasilkan nilai rendemen dan indeks bias yang maksimal yaitu pada suhu $59,28^{\circ} \mathrm{C}$ selama 72,57 menit. Suhu dan waktu optimum menghasilkan karakteristik oleoresin yaitu rendemen sebesar $32,47 \%$, nilai indeks bias sebesar 1,4923 , berat jenis sebesar 1,3740 dan warna oleoresin yang dihasilkan yaitu berwarna kuning dengan bentuk oleoresin yang kental. Komponen yang teridentifikasi dalam oleoresin kulit jeruk lemon hasil optimasi sebanyak 32 macam komponen, dengan pendugaan bahwa komponen yang terdapat dalam oleoresin kulit jeruk lemon yaitu 1-propanone, 1,3,6 Octratriene, Propanoic Acid, 2Furancarboxaldehyde, 4-Vinyl-2-MethoxyPhenol, 1-Pentene, Neryl Acetate, Geranic Acetate, $\alpha$-Bergamotene, Limonene, 2 Hexenal, 2-Bornanone, 2-Decyn-1-ol, Methyl Eugenol, Cis-P-Mentha-1(7),8-dien-2-ol, 1,4 Naphthalendione, Undecanal, Octadecanoic Acid, Pentadecanoic Acid, Decanoic Acid, 11Octadecanoic Acid,Geranyl Butirate, Geranyl Propionate dan 1,2-Benzenedicarboxylic Acid.

\section{Saran}

Berdasarkan penelitian yang telah dilakukan dapat disarankanuntuk melanjutkan penelitian dengan melakukan uji kuantitatif terhadap komponen flavor pada oleoresin kulit jeruk lemon.

\section{DAFTAR PUSTAKA}

AOAC. 1990. Official Method of Analysis of Association Official Agriculture Chemist Washington DC.

Arpi, N., Satriana., dan K. Rezekiah. 2013. Ekstraksi oleoresin dari limbah penyulingan pala menggunakan ultrasonik. Jurnal Rekayasa Kimia dan Lingkungan. 9(4): 180 -187 .

Assagaf, M., P. Hastuti, C. Hidayat, dan Supriyadi. 2012. Optimasi Ekstraksi Oleoresin Pala (Myristica fragrans Houtt) Asal Maluku Utara Menggunakan Response Surface Methodology (RSM). AGRITECH. 32(4): 383-391.

Balachandran S., S.E.Kentish, R.Mawson, danM. Ashokkumar. 2006. Ultrasonic enhancement of the supercritical extraction from ginger. Ultrasonics Sonochemistry. 13(6): 471-479.

Benvenuti F., F. Gironi, dan L. Lamberti. 2001. Supercritical deterpenation of lemon essensial oil, experimental data and simulation of the semicontinous extraction process. Journal Supercritical Fluids. 20(1): 29-44.

Desmawarni. 2007. Pengaruh Komposisi Bahan Penyalut dan Kondisi Spray Drying terhadap Karakteristik Mikrokapsul Oleoresin Jahe. Skripsi. Tidak Dipublikasikan. Fakultas Teknologi Pertanian IPB, Bogor.

Ewansiha, J.U., S.A. Garba, M. Galadima, S.Y. Daniyan, dan M.B. Busari. 2006. Therapeutic potency of Citrus limon (1) burm. F. (lemon) peel extract against some disease causing microorganisms. International Journal of Research Studies in Biosciences (IJRSB). 4(11): 30-39.

Frenkel, D.H. dan R. Dudai. 2016. Biotechnology In Flavor Production, Second Edition. John Wiley \& Sons. Ltd., UK.

Fuadi, A. 2012. Ultrasonik sebagai alat bantu ekstraksi oleoresin jahe. Jurnal Teknologi. 12(1): 14-21. 
Hartuti,S. dan M.D. Supardan. 2013. Optimasi ekstraksi gelombang ultrasonik untuk produksi oleoresin jahe (Zingiber officinale Roscoe) menggunakan respon surface methodology (RSM). Journal Agritech 33(4): 415-423.

Rafsanjani, M.K dan W.D.R. Putri. 2015. Karakteristik ekstrak kulit jeruk bali menggunakan metode ultrasonic bath (kajian perbedaan pelarut dan lama ekstraksi). Jurnal Pangan dan Agroindustri. 3(4): 1473-1480.

Ramadhan, E. dan P.A.Haries. 2010. Pengaruh Konsentrasi Suhu dan Waktu Pada Ekstraksi Oleoresin Kulit Kayu Manis. Skripsi. Tidak Dipublikasikan. Fakultas Teknik Kimia. UNDIP, Semarang.

Rupini, N.P.D., I. W. R. Widarta, dan I. N. K. Putra. 2017. Optimasi suhu dan waktu ekstraksi kulit kayu manis (Cinnamomum burmanii) dengan gelombang ultrasonik menggunakan response surface methodology (RSM). Media Ilmiah Teknologi Pangan (Scientific Journal of Food Technology). 4(1): 52-62.

Sarwono, J. 2006. Metode Penelitian Kuantitatif dan Kualitatif. Penerbit Graha Ilmu, Yogyakarta.

Silfia. 2013. Pengaruh penggunaan cassiavera (Cinnamomum burmanii) mutu rendah terhadap kualitas oleoresin. Balai Riset \& Standarisasi Industri Padang. Jurnal Litbang Industri. 3: 109-105.

Solehudin, M. 2001. Ekstrak Minyak dan Oleoresin dari Kulit Kayu Manis (Cinnamomum burmanii). Skripsi. Tidak Dipublikasian. Fakultas Teknologi Pertanian IPB,Bogor.

Yuliantari, N.W.A., I.W.R. Widarta, dan I.D.G.M. Permana. 2017. Pengaruh suhu dan waktu ekstraksi terhadap kandungan flavonoid dan aktivitas antioksidan daun sirsak (Annona muricata L.) menggunakan ultrasonik. Media Ilmiah Teknologi Pangan (Scientific Journal of Food Technology). 4(1): 35-42. 